\title{
Impact of Privatization on Employees' Treatment towards Share Ownership
}

\author{
Anželika Berḳe-Berga, Riga Technical University
}

\begin{abstract}
The purpose of this paper is to find out whether employee share ownership would have the same impact on the employees from Latvian joint stock companies that underwent privatization in the early 1990s and from the ones without such experience. For the purposes of the analysis the author uses the data from two empirical surveys. The author discovers the current situation in Latvia regarding ESO. The author finds out the opinions regarding share ownership, share purchase, change in employees' motivation and performance considering employees that have experienced privatization and the ones that have not.
\end{abstract}

Keywords: employee share ownership, privatization, psychological ownership, transition economies.

\section{INTRODUCTION}

In the early 1990s together with regaining of Latvia's independence a new economic policy was launched, which implied privatization of the state owned enterprises. In many of them shares were granted to employees. In some research papers this process was considered as the employee share ownership (ESO) [1]. However, the author argues that it was not a genuine ESO due to several reasons. Employee share ownership is participation of employees in redistribution of financial results of their employer company resulting from the ownership of the company's shares or their derivatives, in order to increase employee motivation and productivity (in the present paper called “modern ESO”).

Privatization was a deal between the state and the holders of privatization certificates rather than employee compensation for the results achieved. Consequently, the process of privatization which implied distributing shares of the enterprises to their staff cannot be regarded employee share ownership. Furthermore, many of the public enterprises under privatization were insolvent. Thus, we cannot say that it was real employee share ownership (as we see it in contemporary perspective) in the companies which did not pay wages to their employees. Actually, the main objective of the state regarding privatization of the companies was attracting strategic investors, who would be able to restore the companies, restructure them and invest in further development of these companies.

In many cases, in the process of transition of business ownership from the company staff to its management, the value of shares was reduced for several reasons - inflation, failure to pay dividends, in some cases, so-called share value "dilution" by increasing the number of shares in an additional issue [2]. Consequently, the management of the companies was in a particularly advantageous position to buy shares at a low price from the employees, who were in financial difficulties. In the companies whose shares were granted to employees, the management often used their position selfishly.

As C. Rosen, J. Case and M. Staubus have found, the introduction of ESO alone does not automatically mean the change in attitudes and outcomes of employees. It depends on the formation of owner's attitude or psychological ownership in the employees. Owner's attitude may be developed if employees in the ESO model have: appropriate amount of shares (which the employee considers sufficient); the company creates the internal culture that helps employees to feel as co-owners; and there is a shared understanding of the business and common target [3].

Some features of ESO in Latvia developed during the privatization process. Employees of many companies became co-owners. However, there is no information that any enterprise in Latvia would create ESO models in order to enhance firm performance or boost motivation. The ESO was not organized in an appropriate manner. Employees actually did not know what this new ownership means, what it contains, what one should do with their shares, how to evaluate their potential, etc.

According to the PEPPER IV Report, by the end of 1998, shares with the nominal value of LVL 27 million, amounting to 13.56 per cent of the total shares, had been sold for vouchers to 25,611 employees and former employees of the companies. During the period 1997-1999, employee and former employee ownership decreased by 19.2 percent and 23.3 per cent, accordingly [4].

Although in our opinion employee share ownership through privatization was largely ineffective because the companies did not care about the so-called ownership culture - employees were not considered and treated as owners.

N. Mygind has found that in the early 1990s there was a tendency for relatively low capital intensity in insider owned enterprises [5]. For the reason of easier access to capital markets, the dominant theoretical view is that firms with outside ownership are expected to be more efficient than the firms owned by insiders. At the same time there are arguments that insider ownership may be more conductive to enhance organizational performance [6]. Jones and Mygind have proved that moving away from state ownership has enhanced higher productivity [7].

J. S. Earle and A. Telegdy state that transfer of shares to employees, through giveaways or sales at low prices, has been a common privatization method in transition economies, due to the relative ease of administrative and political implementation. The method is controversial, however, and frequently alleged as unsuited to the restructuring demands of the transition. On the one hand, insider privatization may improve company's results, ensure loyalty of employees, and their support for restructuring. On the other hand, employees may lack the 
necessary skills, capital, and access to markets and technologies necessary to carry out the necessary reforms in the company. They say that corporate governance by employees may function particularly poorly when the firm faces difficult restructuring choices that have disparate distributional impacts within the firm [8].

Only recently some Latvian companies have attempted to introduce modern ESO plans in order to motivate their employees to work more productively, sustain loyalty or reach other goals associated with ESO.

There have been some debates and scientific surveys about employee share ownership during privatization. But the impact of existing or probable share ownership on employees' attitude towards their work in Latvia has not been researched yet. Until now there are no surveys about the treatment of share ownership from employees' point of view. Thus, in this research paper the author would like to discover the evolution of ESO in Latvia through privatization, the consequences of employees' experience as share owners and their attitude and possible change of attitude though share ownership.

\section{Methodology}

For the present research the author used data of two empirical surveys conducted by the author. One is a qualitative survey which includes interviews of experts - senior executives of large and medium joint stock companies from different sectors. The research method was semi-structured interviews. The list of experts is presented in Table 1.

TABLE I

LIST OF SURVEY EXPERTS

\begin{tabular}{|l|l|l|l|l|}
\hline Nr. & Position & $\begin{array}{l}\text { Experience } \\
\text { (years) }\end{array}$ & $\begin{array}{l}\text { Size of } \\
\text { the } \\
\text { company }\end{array}$ & $\begin{array}{l}\text { The company's main } \\
\text { activity }\end{array}$ \\
\hline E1 & Head of HR & 5 & Large & Pharmaceuticals \\
\hline E2 & $\begin{array}{l}\text { Legal } \\
\text { Advisor }\end{array}$ & 8 & Medium & $\begin{array}{l}\text { Elevator construction } \\
\text { and maintenance }\end{array}$ \\
\hline E3 & $\begin{array}{l}\text { Senior } \\
\text { Personnel } \\
\text { Manager }\end{array}$ & 5 & Large & $\begin{array}{l}\text { Wholesale and retail } \\
\text { trade }\end{array}$ \\
\hline E4 & Head of HR & 17 & Medium & Food production \\
\hline E5 & $\begin{array}{l}\text { The } \\
\text { Executive } \\
\text { Director }\end{array}$ & 20 & Large & $\begin{array}{l}\text { Household goods } \\
\text { production }\end{array}$ \\
\hline E6 & $\begin{array}{l}\text { Senior } \\
\text { Personnel } \\
\text { Manager }\end{array}$ & 3 & Medium & $\begin{array}{l}\text { Retail trade of } \\
\text { agricultural goods }\end{array}$ \\
\hline E7 & $\begin{array}{l}\text { Staff } \\
\text { Development } \\
\text { Manager }\end{array}$ & 4 & Large & $\begin{array}{l}\text { Information and } \\
\text { communications } \\
\text { service }\end{array}$ \\
\hline E8 & $\begin{array}{l}\text { Senior } \\
\text { Personnel } \\
\text { Manager }\end{array}$ & 6 & Large & Financial Services \\
\hline E9 & $\begin{array}{l}\text { Managing } \\
\text { Director }\end{array}$ & 5 & $\begin{array}{l}\text { Telecommunications } \\
\text { equipment } \\
\text { manufacturer }\end{array}$ \\
\hline
\end{tabular}

The author used NVivo 8 software for qualitative analysis.
Another survey is quantitative; it includes questionnaires of employees from large and medium joint stock companies in Latvia. The size criterion of enterprises was the number of employees, according to recommendation of the European Commission:

1) More than 250 persons for large enterprises;

2) 50 to 249 persons for medium sized enterprises [9].

According to data of the Register of Enterprises of the Republic of Latvia, there are 65 large JSCs and 141 medium sized ones in Latvia (both - public and over the counter (OTC) companies). In accordance with the information from the Central Statistical Bureau of Latvia, average number of employees in large enterprises is 723 employees, in medium sized -100 employees. Thus, the size of survey population is 61,095 persons.

Our sample consists of 610 employees from 19 large and 42 medium sized companies. The author received 614 responses 140 in the paper form and 474 in the electronic form. The author used SPSS program for the processing of the survey data. For quantitative analysis the author did hypotheses tests (with Chisquare test), correlation analysis and cross tables.

\section{RESULTS}

There are various forms of employee share ownership in the enterprises in Latvia. Some companies successfully continue to maintain the post-privatization model; in some companies employees have sold their shares to the top management or, in most cases, to foreign investors. Some companies are listed on the stock exchange and the employees purchase shares in the stock market. The author has also found several companies (subsidiaries of large international concerns) that have introduced modern ESO. One of them participated in our qualitative survey.

In order to establish the characteristics of company shareholders, the author compiled Table 2, which shows the estimated number of shareholders, whether the shares are listed on the stock exchange, whether there are employeesshareholders, the nationality of the shareholders, and their legal status.

TABLE II

DESCRIPTION OF THE COMPANIES' SHAREHOLDERS

\begin{tabular}{|l|l|l|l|l|l|}
\hline Expert & $\begin{array}{l}\text { Stock } \\
\text { exchange } \\
\text { /OTC } \\
\text { company }\end{array}$ & $\begin{array}{l}\text { Number of } \\
\text { shareholders }\end{array}$ & $\begin{array}{l}\text { Employees - } \\
\text { shareholders }\end{array}$ & Nationality & $\begin{array}{l}\text { Legal } \\
\text { status }^{1}\end{array}$ \\
\hline E1 & $\begin{array}{l}\text { Stock } \\
\text { exchange }\end{array}$ & $\begin{array}{l}5 \text { large + } \\
\text { minority } \\
\text { shareholders }\end{array}$ & yes & various & $\begin{array}{l}\text { PP } \\
\text { and } \\
\text { LP }\end{array}$ \\
\hline E2 & OTC & 1 & no & foreign & LP \\
\hline E3 & OTC & $\begin{array}{l}\text { A small } \\
\text { group of } \\
\text { people }\end{array}$ & no & local & PP \\
\hline E4 & OTC & $\begin{array}{l}1 \text { large } \\
(>90 \%)+ \\
\text { minority } \\
\text { shareholders }\end{array}$ & yes & various & PP, \\
LP
\end{tabular}

${ }^{1} \mathrm{PP}$ - private person, $\mathrm{LP}$ - legal person 


\begin{tabular}{|l|l|l|l|l|l|}
\hline E5 & OTC & Around 500 & yes & various & $\begin{array}{l}\text { PP, } \\
\text { LP }\end{array}$ \\
\hline E6 & OTC & $\begin{array}{l}\text { Several } \\
\text { dozens }\end{array}$ & yes & local & $\begin{array}{l}\text { PP, } \\
\text { LP }\end{array}$ \\
\hline E7 & OTC & 1 & no & foreign & LP \\
\hline E8 & $\begin{array}{l}\text { Stock } \\
\text { exchange }\end{array}$ & $\begin{array}{l}\text { minority } \\
\text { shareholders }\end{array}$ & yes & various & $\begin{array}{l}\text { PP, } \\
\text { LP }\end{array}$ \\
\hline E9 & $\begin{array}{l}\text { Stock } \\
\text { exchange }\end{array}$ & $\begin{array}{l}5 \text { large + } \\
\text { 500 } \\
\text { minority } \\
\text { shareholders }\end{array}$ & yes & various & $\begin{array}{l}\text { PP, } \\
\text { LP }\end{array}$ \\
\hline
\end{tabular}

Many employees who acquired shares during privatization (mostly from 1992 till 1994) sold them shortly after obtaining at a very low price. Several experts (E1, E2 and E6) admitted that in the early 1990s most of the employees sold their shares mainly to the top management at a very low price and now (if they still are in the company), when they see current prices, it is a painful issue for them and they regret the steps taken before. The experts told that during the early stage of privatization no one explained to employees the meaning of share ownership and definitely did not create the modern ESO as we know and understand it today.

Expert E2 admitted that contemporary ESO might work well in the companies with rather young staff (till age of 40 or 50).

However, there were also those who understood the nature of ownership of shares, and saw their potential for the future. Many of these employees have already retired and continue to hold the shares. Others sold them or transferred by inheritance. There are also employees, who still hold the shares or are ready to sell them if they receive an attractive proposition. Employees from the companies listed on the stock exchange sometimes buy shares in the stock market either on their own initiative or encouraged by the employer.

One of the researched companies (E5) is up to $85 \%$ owned by its employees. The employees are very loyal to the company and they are proud to be co-owners. They got shares during the early stage of privatization and the criteria of granting shares was the time each employee had worked for the company. The new employees who join the company do not get shares. They can buy them if any of the existing shareholders are willing to sell their shares. Employees of this company are interested in share ownership.

In a large proportion of companies (6 of 9) in which interviews were conducted (see Table 2), employees own shares. Three companies are listed on the stock exchange, where everyone, including the staff, is free to buy shares.

Only in one company (E4), where employees used to own stocks (few of them still have), share ownership is not the motivating factor, rather the contrary, because the share value has declined. The expert admitted that the share value has decreased and the value of the money invested in share purchase has also been reduced by inflation. Thus, employees have double losses. They received no dividends as the majority owners for many years decided to invest all the profits in further development of the company. As the employees in E4 company together had less than $10 \%$ of shares, their voting rights had no significant impact.

In some companies majority owners are senior management members, for example, E1 and E9. E5 company is owned by the majority of employees and the management. The employees are highly satisfied with the existing model. In addition, the company's major shareholders have the position that the shares are not traded to foreign or outside investors. Only those that are directly associated with the company may purchase shares.

As mentioned before, one of the surveyed companies maintains a modern ESO model. They have several different ESO plans. One of them is broad based ESO. Employees have an opportunity to spend till $10 \%$ of their salary for share purchase. If they stay with the company and hold the shares for 3 years period, the employer doubles the amount of shares in their accounts. After the freezing period (3 years) employees are allowed to dispose of their shares freely. About one tenth of the employees have agreed to participate in this ESO plan.

The same company has another ESO plan for its top management. It is done through stock options. Management has to achieve predetermined targets and their work and decisions are evaluated and influence the amount of the ESO bonus. The management program is set for longer terms and there are bigger bonuses which depend on the effectiveness.

According to our and other surveys, the main obstacles that make implementation of ESO in the Latvian companies inconvenient, are lack of appropriate legal basis, disadvantageous taxation policy and lack of information about ESO implementation, case studies, etc.

The main goal of the quantitative study was to find out whether employees in the Latvian companies do or would perceive share ownership in the same way as theory tells us. Would it be a motivating factor for them? Has the privatization experience left some prejudice or negative associations, maybe even feelings that they might be cheated again?

The quantitative study included 614 respondents, of which $37 \%$ (227) work in medium-sized enterprises and $63 \%$ of staff (387) are employees of large joint stock companies. Regarding the rank of respondents, they represent the following categories: $8.3 \%$ (51) key management personnel, 42.7\% (262) middle managers, $30.9 \%$ (190) qualified specialists, $5.5 \%$ (34) sales professionals, and $12.5 \%$ (77) other representatives. The survey participants divided by age groups are: $23.8 \%$ (146) under the age of 25, 49.2\% (302) aged 26-40, 23.6 (145) aged 41-55 and $3.4 \%(21)$ over 55 years.

To the question "Do you own shares of the Company," 41 respondents answered in affirmative, which is $6.7 \%$ of the total number of employees surveyed. Of these, $13(31.7 \%)$ have purchased shares on the stock exchange, $20(48.8 \%)$ - received as a bonus from their employer, and $8(19.5 \%)$ acquired the shares in the privatization process. $93.3 \%$ (573) of the respondents do not own shares of the employer company.

Comparing the age groups and ways of getting shares (see Table 3), it can be concluded that both groups (privatization experienced respondents (older than 40) and past privatization respondents (younger than 40)) own shares in almost equal proportion. Approximately $20 \%$ got their shares during privatization. The rest $80 \%$ got them as a bonus from the employer $(49 \%)$ or bought them on the stock exchange $(31 \%)$. 
TABLE III

INTERRELATION BETWEEN AGE GROUPS AND WAYS OF GETTING SHARES

\begin{tabular}{|l|l|l|l|l|l|l|}
\hline \multicolumn{2}{|c|}{} & \multicolumn{3}{|l|}{ Age groups } & \multirow{2}{*}{ Total } \\
\cline { 3 - 7 } \multicolumn{2}{c|}{} & $\begin{array}{l}\text { Till } \\
25\end{array}$ & $\begin{array}{l}26- \\
40\end{array}$ & $\begin{array}{l}41- \\
55\end{array}$ & $\begin{array}{l}\text { Over } \\
55\end{array}$ & \\
\hline $\begin{array}{l}\text { How did } \\
\text { you get } \\
\text { the } \\
\text { shares? }\end{array}$ & $\begin{array}{l}\text { Purchased on the } \\
\text { stock exchange }\end{array}$ & 1 & 6 & 5 & 1 & 13 \\
\cline { 2 - 7 } & $\begin{array}{l}\text { Received as a bonus } \\
\text { from my employer }\end{array}$ & 1 & 10 & 7 & 2 & 20 \\
\cline { 2 - 7 } & $\begin{array}{l}\text { Got them during } \\
\text { privatization }\end{array}$ & 0 & 3 & 3 & 2 & 8 \\
\hline Total & 2 & 19 & 15 & 5 & 41 \\
\hline
\end{tabular}

The next task is to determine whether there are differences among the respondents who have purchased shares on the stock exchange, received them as a bonus or during the time of privatization (V7) and the importance of benefits these people have received from shares (from V10_1 to V10_5). To clarify this, the author carried out hypothesis test with a chi-square test for the following hypotheses:

$\mathrm{H}_{0}$ : There is no significant difference between opinions about the benefits they can receive from shares among groups of respondents (differentiated by ways of obtaining stocks).

$\mathrm{H}_{1}$ : There is a significant difference between opinions about the benefits they can receive from shares among groups of respondents (differentiated by ways of obtaining stocks).

It was approved by the null hypothesis in all cases, so the importance of receiving the stock bonuses does not depend on the way in which staff got their shares.

To assess the impact of privatization period experiences on the treatment to the acquisition of shares, the respondents were divided into two age groups:

a) Those who were not yet of working age at the time of privatization (i.e., did not have the first-hand experience): age group "till 25" and "26-40", in total 448 respondents;

b) Those who were of working age during privatization: the age group "41-55" and "over 55", in total 166 respondents.

Then the author did cross-tabulation of age groups and attitude towards share purchase with a $50 \%$ discount and freezing period for 3 years (see Table 4 ).
TABLE IV

IMPACT OF PRIVATIZATION PERIOD ON EMPLOYEES' ATTITUDE TOWARDS SHARE PURCHASE

\begin{tabular}{|c|c|c|c|c|c|c|c|}
\hline & & \multicolumn{5}{|c|}{$\begin{array}{l}\text { If you have an opportunity to buy shares of the } \\
\text { Company with a } 50 \% \text { discount, provided that } \\
\text { such shares will be frozen for } 3 \text { years period, } \\
\text { you would: }\end{array}$} & \multirow[b]{2}{*}{ Total } \\
\hline & & $\begin{array}{l}\text { Buy them } \\
\text { for }>=30 \% \\
\text { of your } \\
\text { income }\end{array}$ & $\begin{array}{l}\text { Buy for } \\
20 \%\end{array}$ & $\begin{array}{l}\text { Buy for } \\
10 \%\end{array}$ & $\begin{array}{l}\text { Buy for } \\
\text { premium }\end{array}$ & $\begin{array}{l}\text { Would } \\
\text { not buy }\end{array}$ & \\
\hline \multirow{4}{*}{$\begin{array}{l}\text { Age } \\
\text { groups }\end{array}$} & Till 25 & 32 & 31 & 30 & 20 & 33 & 146 \\
\hline & $26-40$ & 42 & 49 & 69 & 77 & 65 & 302 \\
\hline & $41-55$ & 15 & 12 & 37 & 32 & 49 & 145 \\
\hline & $\begin{array}{l}\text { over } \\
55\end{array}$ & 3 & 3 & 5 & 4 & 6 & 21 \\
\hline \multicolumn{2}{|l|}{ Total } & 92 & 95 & 141 & 133 & 153 & 614 \\
\hline
\end{tabular}

Evaluating responses of the youngest group, $22 \%$ of them would not have purchased the shares at a discount, and $78 \%$ would buy them. A group that experienced the privatization period has a more cautious attitude $-67 \%$ would purchase shares. The difference is not very significant and thereby it can be concluded that people feel much safer today regarding an opportunity to purchase stocks. This may also be due to improvements in securities market infrastructure and information availability.

The difference between groups regarding share purchase can be explained by both the privatization experience and the risk "appetite" decline with ageing. The correlation coefficient for the age groups and the issue of V11 indicates that the relationship between variables can be assessed as weak (0.158).

Another question regarded the attitude towards share purchase from the existing shareholders (see Table 5).

TABLE V

INFLUENCE OF PRIVATIZATION EXPERIENCES ON EMPLOYEES' ATTITUDE TO ACQUISITION OF SHARES

\begin{tabular}{|c|c|c|c|c|c|c|c|}
\hline & & \multicolumn{5}{|c|}{$\begin{array}{l}\text { If any of the shareholders of the Company would } \\
\text { inform that they wanted to sell their shares, would } \\
\text { you be willing to buy some of them? }\end{array}$} & \multirow[b]{2}{*}{ Total } \\
\hline & & $\begin{array}{l}\text { Yes, } \\
\text { definitely }\end{array}$ & $\begin{array}{l}\text { If I had } \\
\text { free } \\
\text { capital } \\
\text { then yes }\end{array}$ & $\begin{array}{l}\text { I would } \\
\text { consider it } \\
\text { depending on } \\
\text { the price }\end{array}$ & $\begin{array}{l}\text { No, I } \\
\text { have } \\
\text { no } \\
\text { interest }\end{array}$ & $\begin{array}{l}\text { No } \\
\text { way! }\end{array}$ & \\
\hline \multirow[t]{4}{*}{$\begin{array}{l}\text { Age } \\
\text { groups }\end{array}$} & $\begin{array}{l}\text { Below } \\
25\end{array}$ & 19 & 56 & 42 & 19 & 10 & 146 \\
\hline & $26-40$ & 39 & 113 & 94 & 42 & 14 & 302 \\
\hline & $41-55$ & 8 & 58 & 34 & 33 & 12 & 145 \\
\hline & over 55 & 3 & 9 & 5 & 2 & 2 & 21 \\
\hline \multicolumn{2}{|l|}{ Total } & 67 & 236 & 175 & 96 & 38 & 614 \\
\hline
\end{tabular}

Evaluating the responses of the youngest group, $19 \%$ of them would not have purchased the shares, $81 \%$ would purchase. The group who experienced the privatization period is more cautious in their attitude $-71 \%$ would purchase shares. 
Although there is a difference between both age groups in their attitude towards the acquisition of shares by comparing the response to the previous question, in all age groups there is a growing number of persons interested in the acquisition of shares. Perhaps it is because of the "freezing period" mentioned in the previous question.

The correlation coefficient for the age groups and share purchase from the existing shareholders indicates that the relationship between the variables can be assessed as weak (0.067).

The employees who owned shares $(\mathrm{N}=41)$ were asked about the factors that were important for them regarding share ownership. Employees-owners noted that the most important factors for them in the context of share ownership were financial benefits from shares - dividends and increase in value (68\% and $56 \%$ of respondents who own shares gave the highest rating of importance, see details in Fig. 1). Receiving information was important for $36 \%$. $25 \%$ valued voting rights. Currently in Latvia voting rights for personnel share owners are not legally provided. The author supposes that entrepreneurs (and not the state) should have an opportunity to take decisions with regard to granting voting rights in ESO plans or not.

The least valuable for employees co-owners is the higher status in the society sometimes associated with share ownership.

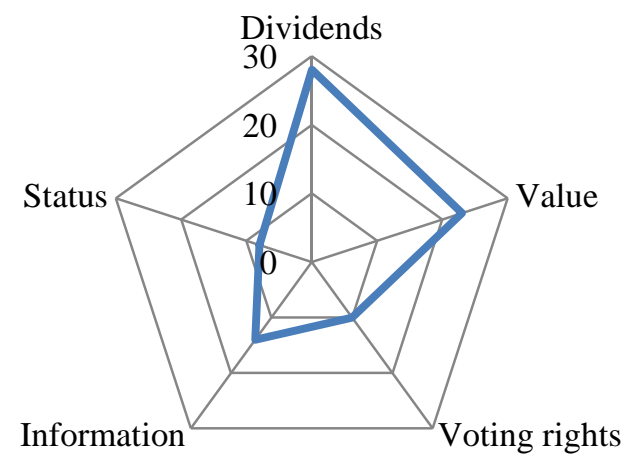

Fig.1 Employees-shareholders important factors related to stock ownership.

$250(41 \%)$ survey respondents noted that they work in a public company. When asked about how often they check the share prices of their employer's company, most respondents answered that they actually do not seek and care about the stock price changes in the market (152 respondents or $61 \%$, see Figure 2). $24(9 \%)$ of the respondents are following the fluctuations of stock prices daily, 42 (17\%) - once a month, 32 $(13 \%)$ - about once a year.

$160(26.1 \%)$ of the respondents work in the companies over the counter, while 204 (33.2\%) of the participants stated they do not know whether the company shares are quoted on the stock exchange or not. Thus, it can be concluded that the overall knowledge about stocks and stock exchange market is rather low and companies do not inform their employees about these issues.

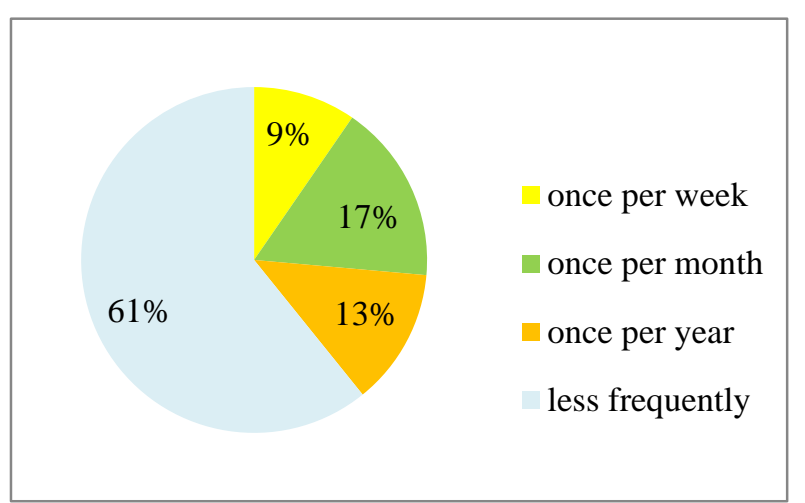

Fig. 2. The regularity of following up the information about shares of employees of publicly traded companies about share prices

N. Mygind mentions that insider ownership, and especially employee share ownership, are considered to have specific disadvantages regarding the performance of the company, because employees might have special objectives of ensuring stable jobs and high wages, which contradict the objective of profit maximization. The disadvantage of employee share ownership might also be that employees might lack the necessary management skills and they have limited access to capital [10].

Contrary to this opinion, there are many empirical surveys proving that enterprises with ESO perform much better than their peers without employee shares. For example F. Fakhfakh, V. Perotin and M. Gago have researched employee performance in different industries in France. Their survey approves that employee owned companies grow faster and are more productive [11]. J. Blasi and D. Cruse have gathered empirical results from 30 surveys conducted in the United States in order to examine the impact of ESO. The majority of the surveys showed either positive or neutral result. In none of them ESO caused negative consequences. Average difference in performance was $4-5 \%$ more in the enterprises maintaining the ESO schemes [12]. The same authors in other survey studied 105 listed companies in the United States with broad-based ESO and also found positive impact of ESO [13]. There are many other empirical surveys attesting that better performance is observed in the enterprises where employees are co-owners.

In the early nineties in Latvia almost no one in the management of enterprises cared about employee share ownership development. During privatization the most widespread way of ownership transfer was to find an outside investor. Another way would be developing the existing ESO till its genuine manifestation.

The author wanted to find out whether Latvian employees would perform better in companies as co-owners. The author asked a question to the respondents of the survey conducted: how $\mathrm{did} /$ would their work performance change if they were coowners of the company (see Table 6). 
TABLE VI

INFLUENCE OF PRIVATIZATION EXPERIENCES ON EMPLOYEES' ATTITUDE TO THEIR PERFORMANCE IMPROVEMENT OPPORTUNITIES

\begin{tabular}{|c|c|c|c|c|c|c|}
\hline & & \multicolumn{4}{|c|}{ Age groups } & \multirow[b]{2}{*}{ Total } \\
\hline & & $\begin{array}{l}\text { Till } \\
25\end{array}$ & $\begin{array}{l}26- \\
40\end{array}$ & $\begin{array}{l}41- \\
55\end{array}$ & $\begin{array}{l}\text { over } \\
55\end{array}$ & \\
\hline \multirow{2}{*}{$\begin{array}{l}\text { How would/did your } \\
\text { productivity change when } \\
\text { becoming a shareholder? }\end{array}$} & Improve & 94 & 158 & 54 & 9 & 315 \\
\hline & $\begin{array}{l}\text { Remain } \\
\text { unchanged }\end{array}$ & 52 & 144 & 91 & 12 & 299 \\
\hline \multicolumn{2}{|l|}{ Total } & 146 & 302 & 145 & 21 & 614 \\
\hline
\end{tabular}

It can be seen that $51 \%$ of respondents associate share ownership with productivity improvement. The group that had direct experience of privatization is more conservative regarding productivity change. One of the explanations for this may be that the employees belonging to this group already work with the best effort and share ownership would not change their attitude. Only $38 \%$ of the respondents over 40 years of age would be able to improve their productivity and associate it with share ownership. The respondents that did not have direct relationship with share ownership through privatization are probably more materialistic or more interested in share ownership. $56 \%$ of them would be able to improve their productivity becoming shareholders.

\section{CONCLUSIONS}

Most of the studies on the ESO done in Latvia in general reflect and describe the historical situation of privatization, experience and problems of that time. Our study analyses current situation of ESO in Latvia and attitude of employees towards share ownership. The author tried to evaluate whether privatization experience had left some negative reflections associated with employee share ownership.

In Latvia there is a specific historical experience of ESO gained through privatization mostly during the beginning of the 1990s. Many companies granted their shares to employees but they did not build or develop ownership culture among their employees. Therefore, the practice of privatization cannot be regarded as modern employee share ownership practice.

The author found out that there are companies that adopted different forms of employee share ownership (or without it):

a) companies with employees-owners since privatization:

a. having positive experience,

b. having negative experience,

b) listed companies with employees co-owners (both management and staff),

c) companies with managers co-owners,

d) companies without ESO,

e) companies with modern ESO.

More than $75 \%$ of survey respondents expressed interest in the opportunity of buying shares in their employer's company. The group of respondents younger than 40 years of age had more positive attitude towards the acquisition of shares. The experienced group was less willing to purchase shares. The difference between both groups was approximately $10 \%$.
Thereby it can be concluded that privatization might have left a negative impact on employees' attitude towards share purchase. However, there may be other influencing and reinforcing factors as well, e.g. risk appetite decline with ageing and potential better knowledge and understanding about modern financial markets among younger employees.

\section{REFERENCES}

[1] Lowitzsch, J., et.al., The PEPPER IV Report: Benchmarking of Employee Participation in Profits and Enterprise Results in the Member and Candidate Countries of the European Union, Berlin, May 2008, 244 p.

[2] Lowitzsch, J., et.al. The PEPPER III Report: Promotion of Employee Participation in Profits and Enterprise Results in the New Member and Candidate Countries of the European Union, Rome and Berlin, June 2006, p. 186.

[3] Rosen, C., Case, J., Staubus, M., Equity: Why Employee Ownership is Good for Business, Boston: Harvard Business School Press, pp. 32-34, 2005.

[4] Lowitzsch, J., et.al., The PEPPER IV Report: Benchmarking of Employee Participation in Profits and Enterprise Results in the Member and Candidate Countries of the European Union, Berlin, May 2008, 244 p 117.

[5] Mygind, N. Privatization, Governance and Restructuring of Enterprises in the Baltics. OECD, October 1999 [Online]. Available: http://www.oecd.org/corporate/ca/corporategovernanceprinciples/19315 48.pdf [Accessed: Sep. 7, 2013], p.12.

[6] Jones, D. C., Mygind, N. "The Effects of Privatization on Productive Efficiency: Evidence from the Baltic Republics" in the Annals of Public and Cooperative Economics, Vol. 71, No. 3, p. 416, 2000.

[7] Jones, D. C., Mygind, N. "The Effects of Privatization on Productive Efficiency: Evidence from the Baltic Republics" in the Annals of Public and Cooperative Economics, Vol. 71, No. 3, p. 432, 2000.

[8] Earle, J. S., Telegdy, A. Privatization Methods and Productivity Effects in Romanian Industrial Enterprises in the Journal of Comparative Economics, Vol. 30, p. 663, 2002.

[9] Commission recommendation of 6 May 2003, concerning the definition of micro, small and medium-sized enterprises (2003/361/EC), Title II, Article 7, May 2003 [Online]. Available: http://www.em.gov.lv/images/modules/items/MVUD_130710_3.pdf [Accessed: Nov. 20, 2012]

[10] Mygind, N. Privatization, Governance and Restructuring of Enterprises in the Baltics. OECD, October 1999 [Online]. Available: http://www.oecd.org/corporate/ca/corporategovernanceprinciples/19315 48.pdf [Accessed: Oct. 1, 2013], p.14.

[11] Fakhfakh, F., Perotin, V., Gago, M. Productivity, capital, and labor in labor-managed and conventional firms: An investigation on French data in the Industrial and Labor Relations Review, Vol. 65, Issue 4, pp. 847-879, October 2012.

[12] Rosen, C., Case, J., Staubus, M. Why Employee Ownership is Good for Business, Boston: Harvard Business School Press, p. 38, 2005.

[13] Rosen, C., Case, J., Staubus, M. Why Employee Ownership is Good for Business, Boston: Harvard Business School Press, p. 12, 2005.

Anželika Berḳe-Berga holds a PhD Degree from Riga Technical University. She graduated her doctoral studies in RTU Faculty of Engineering Economics and Management in 2013. Her PhD Thesis is focused on employee share ownership issues.

Currently she is a docent at Riga Stradins University, 16 Dzirciema Street, Riga, LV-1007. There she reads tree study courses for Bachelor program students: "International Financial Relations and European Monetary Union", "Fundamentals of Finance" and "Securities Market. European Experience". She also supervises study papers, Bachelor and Master papers on the subjects concerning financial market, securities, investment funds, banking and other subjects.

Her scientific interests are financial markets and employee share ownership. Address: Stradins University, 16 Dzirciema Street, Riga, LV-1007 Email address: Anzelika.Berke-Berga@ rsu.lv 
Anželika Berḳe-Berga. Privatizācijas ietekme uz darbinieku attieksmi pret akciju īpašumtiesībām

Šì raksta galvenais mērḳis ir noskaidrot, vai pret darbinieku līdzdalību uzṇēmuma kapitālā (DLK) Latvijas akciju sabiedrību darbinieku vidū būtu vienāda attieksme tiem, kuri ir pieredzējuši uzṇēmumu privatizāciju, un tiem, kuriem nav tiešas pieredzes uzṇēmumu privatizācijā. Pētījuma izstrādes gaitā tika izmantoti divu empīrisko pētījumu rezultāti, noskaidrojot, kāda ir patreizējā DLK situācija Latvijā. Pētijjumos tika noskaidrota darbinieku attieksme pret akciju iegādi, īpašumtiesībām, iespējamām pārmaiṇām darbinieku motivācijā un rezultativitātē.

Lielākā daḷa pētījumu par DLK Latvijā pamatā atspogulo un apraksta vēsturisko situāciju, kas saistīta ar privatizācijas periodu, tā laika pieredzi un problēmām. Pētijumā analizêta esošā DLK situācija un darbinieku attieksme pret akciju īpašumtiesībām sava darba devēja uzņēmumā. Autore veica novērtējumu tam, vai privatizācijas pieredze ir atstājusi kādas negatīvas asociācijas, kas saistās ar uzn̄ēmumu privatizāciju un akciju pieškiršanu darbiniekiem 90. gadu sākumā. Šajā periodā tāda privatizācijas metode bija samērā izplatîta. Daudzi uzṇēmumi piešķīra akcijas saviem darbiniekiem, taču netika veidota un attīstîta t.s. īpašnieku kultūra darbiniekos. Līdz ar to privatizācijas pieredzi nevar uzskatīt par pilnvērtīgu DLK tās mūsdienu izpratnē.

Pašreiz Latvijā pastāv uznēmumi ar dažāāām DLK pakāpēm: uznēmumi, kur arī darbinieki ir īpašnieki (ar pozitīvu un negatīvu pieredzi); biržas uznēemumi, kur darbinieki iegādājušies akcijas biržā (tātad, tā nav uzṇēmuma organizēta un iniciēta DLK); uzṇēmumi, kur vadošie darbinieki ir līdzīpašnieki; uzṇēmumi ar mūsdienīgu DLK, kā arī uzṇēmumi, kur nevienam no darbiniekiem akcijas nepieder.

Pētījuma ietvaros tika veikta lielo un vidējo akciju sabiedrību darbinieku anketēšana, kurā noskaidrojās, ka vidēji vairāk kā $75 \%$ respondentu iegādātos uzṇēmuma akcijas un piedalītos arī kādā ilgtermiṇa motivēšanas programmā, kur paredzēta akciju iegāde. Starp respondentu grupām (lielāks vecums un mazāks vecums par 40 gadiem) attiecībā par akciju iegādi bija 10\% atšķirība. No vecākās grupas akcijas iegādātos mazāk darbinieku. To var skaidrot gan ar privatizācijas pieredzi, gan arī ar riska vēlmes mazināšanos līdz ar vecumu, kā arī, iespējams, ar zināšanu un izpratnes līmeña par mūsdienu finanšu tirgiem atškirīibu abās grupās.

\section{Анжелика Берке-Берга, Влияние приватизации на отношение сотрудников к соб̈стенности на акции}

Основной целью данной работы является установление того, есть ли разница между сотрудниками акционерных обществ, кто непосредственно сталкиваются с приватизацией, и теми, кто не имеет прямого опыта в приватизации, в отношении к участию сотрудников в капитале компании (долевой собственности работников, ДСР). При разработке исследования использовались два эмпирических исследований для выяснения текущей ДСР ситуации в Латвии. Исследования выясняет отношение работников на покупку ценных бумаг компании работодателя, право собственности, возможные изменения в мотивации и эффективности.

Большинство исследований о ДСР в Латвии во многом отражают и описывают историческую ситуацию в связи с приватизацией, опыт и проблемы того периода. Наше исследование анализирует текущую ситуацию ДСР, отношение сотрудников акционерных обществ к своему работодателю. Автор попыталась оценить, оставила ли приватизация негативные ассоциации, связанные с приватизацией предприятий в 90-е годы и были ли предоставлены сотрудникам акции в начале этого периода. В течение этого периода способ приватизации предприятий сотрудниками был довольно распространенным явлением. Многие компании предоставляли акций своим работникам, но не была разработана и создана так называемая культура работниковсовладельцев. Следовательно, приватизационный опыт не может считаться полной ДСР в ее современном понимании.

В настоящее время латвийские компании являются с разным уровнем ДСР: компании, в которых работники являются собственниками (как с положительным, так и отрицательным опытом); компании фондовой биржи, где сотрудники приобрели акций (то есть, компания не является инициатором и организатором ДСР); компаний, где руководители являются совладельцами; компании с современным ДСР; а также компании, где ни один из сотрудников не владеет акциями.

Изучения и исследования мнений сотрудников крупных и средних акционерных компаний показало, что в среднем, более 75 \% респондентов позитивно реагировали на возможность приобретения акций компании и участие в долгосрочной программы стимулирования, которая предусматривает приобретение акций. Среди группы респондентов старше 40 лет и моложе на желание приобретения акций составляет разницу около $10 \%$. Старшие сотрудники менее предпочитают приобретение акций. Это может быть объяснено как с опытом приватизации, а также тем, что склонность к риску уменьшается с возрастом, а также с возможной разницей между этими двумя группами в знание и понимание сегодняшних финансовых рынков.

The publication has been developed with the support of the European Social Fund (ESF) within the project "Support for the Implementation of Doctoral Studies at Riga Technical University - 2".

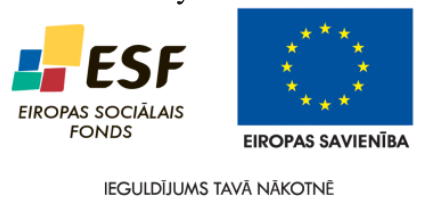

